\title{
Colostrum composition of cows after twin- and triplet-calving
}

\author{
J. Csapó ${ }^{1,2}$ \\ Cs. Albert ${ }^{2}$ \\ e-mail: csapo.janos@gmail.hu \\ e-mail: albertcsilla@cs.sapientia.ro

$$
\text { G. } \text { Bakos }^{3}
$$ \\ e-mail: gaborbakos@hotmail.hu

\section{Szabari ${ }^{5}$} \\ e-mail: szabarim@gmail.com

$$
\begin{gathered}
\text { Á. } \mathrm{Nagy}^{4} \\
\text { e-mail: nagy.adam@gtrt.hu } \\
\text { J. Stefler } 6 \\
\text { e-mail: steflerj@gmail.com }
\end{gathered}
$$ \\ ${ }^{1}$ University of Debrecen, Faculty of Agricultural and Food Sciences and \\ Environmental Management, Institute of Food Technology, \\ HU-4032 Debrecen, Böszörményi út 138. \\ ${ }^{2}$ Sapientia Hungarian University of Transylvania (Cluj-Napoca, Romania), \\ Faculty of Economics, Socio-Human Sciences and Engineering, \\ Department of Food Science, RO-530104 Miercurea Ciuc, 1 Libertăţii Sq. \\ ${ }^{3}$ Bos-Frucht Agricultural Cooperative, Kazsok. \\ ${ }^{4}$ Gödöllő Experimental Farm Ltd., Kartal. \\ ${ }^{5}$ AB 2012 Ltd., Kaposvár \\ ${ }^{6}$ Kaposvár University, Faculty of Agricultural and Environmental Sciences
}

\begin{abstract}
Earlier we determined the colostrum and milk composition of cows after single- and twin-calving as well as the changes in the composition as a function of postpartum time. It was established that the dry matter, protein, whey protein, and immunoglobulin-G (IgG) content
\end{abstract}

Keywords and phrases: first-milked colostrum, protein content, protein fractions, immunoglobulin-G, cattle 
of the first-milked colostrum immediately after calving was significantly higher with twin-calving cows than with single-calving animals. As regards the other components, there were no significant differences among the animals. During the last years, we managed to collect the first-milked colostrum from five cattle after triplet-calving. The composition of these samples were determined by the methods we used earlier at twin-calving animals, and the results were compared to the colostrum composition of single- and twin-calving animals. It was found that although as an effect of triplet-calving the protein and IgG content of colostrum increased, the difference was not significant between twin- and triplet-calving animals. We are aware that others have not reported data from the point of view of the colostrum composition of twin-calving, and in the case of tripletcalving our results are unique in the world. In our publication, we report on the results of our investigations.

\section{Introduction}

Between 1980 and 1990, in connection with the cattle breed restructuring and new cattle breed producing programmes, we determined the colostrum and milk composition of hundreds of cows resulted from crosses between HolsteinFriesian and Jersey cows (Csapó et al., 1982a, 1982b, 1982c; Csapó \& Csapó, 1984). Our investigations were performed at the Hajdúnánás State Farm and at Szigetvár State Farm. During the examination of the composition of firstmilked colostrum, it was found that the colostrum of twin-calving animals had more dry matter, total protein, whey protein, and in particular more immunoglobulin G ( $\operatorname{IgG}$ ) than the single-calving ones (Csapó, 1995). Then, we systematically collected the first milk colostrum of twin-calving animals, and the colostrum composition was compared to the composition of singlecalving animals. At the Hajdúnánás State Farm, we investigated the firstmilked colostrum of 17 single-calving and 17 twin-calving Holstein-Friesian paternity cows, five of which calved bull calf, five heifer calf, seven calved one bull, and one heifer calf. At Szigetvár State Farm, we investigated the first milk colostrum of 15 twin-calving cows, four of which calved bull calf, three heifer calf, and eight calved one bull and one heifer calf. Whereas in all cases the gender of the calves was known, we could investigate the impact of the gender of the calves on the composition of the first-milked colostrum.

Comparing the colostrum composition of the single- and twin-calving cows, it was established that the colostrum of the twin-calving animals contained significantly more dry matter, total protein, true protein, whey protein, true whey protein, and IgG than that of cows with single calving. In contrast, there 
were no significant differences in the casein and non-protein nitrogen (NPN) content between the two groups.

According to the results of our investigations, there are no differences in the colostrum composition between the cows that calved different calves. It seems therefore that the gender of the calves at twin-calving has no effect on the colostrum composition. The biological value of the colostrum from twincalving animals calculated on the amino acid composition was higher with 9.4 in both state farms than that of single-calving animals. The higher biological value can be explained with the higher whey protein content of the colostrum because the biological value of the whey protein is significantly higher than that of the casein. We were unable to confirm the differences by mathematical statistical analysis. Significant differences were not found in the macro- and microelement content of the colostrum between the twin- and single-calving animals (Csapó et al., 1991a; 1991b).

The protein fractions, amino acid composition, and biological value are indicative of the differences between the colostrum composition of single- and twin-calving animals, whereas the IgG is part of the whey protein, the whey protein is part of the total protein, primarily due to IgG or whey protein surplus (Csapó, 2013).

In the national and foreign literature dealing with animal breeding and milk production, we did not find any information with regard to twin pregnancy having any effect on the composition of the colostrum, and therefore we could not evaluate our data in the light of the scientific literature. In addition, based on this, we assumed that our investigations are unique in this area. After this, we received the first milk colostrum of three Holstein-Friesian paternity cows from the Hajdúnánás State Farm, of one Holstein-Friesian cow from Bos-Frucht Agricultural Cooperative, Kazsok, and of one from Gödöllő Experimental Farm Ltd., Kartal, after triplet-calving. In our publication, we report on the composition of the first milk colostrum of triplet-calving animals, and we compare the colostrum composition of twin- and triplet-calving animals.

\section{Literature review}

A lot of information has been published in the literature on the passive immunity of the calves (Ehrlich, 1892), the own immunoglobulin synthesis of the calf during intrauterine life (Mielke, 1979a), calves born with agammaglobulinaemia (Mc Guireet al., 1976; Losonczy et al., 1979), production and synthesis 
of the colostrum (Mielke, 1979b), dependence of the colostrum composition on breed, duration of the lactation, and drying period (Mielke, 1979a). The IgG content of the colostrum was measured between $50 \mathrm{mg} / \mathrm{ml}$ (Butler, 1969; Logan et al., 1981) and $144 \mathrm{mg} / \mathrm{ml}$ (Senft et al., 1976), and the average values ranged between 100 and $110 \mathrm{mg} / \mathrm{ml}$. According to our investigations (Csapó, 1995), the Jersey gene ratio did not change significantly the IgG content of the firstmilked colostrum; the IgG content of the first-milked colostrum was the lowest in a Jersey paternity cow $(61.4 \mathrm{mg} / \mathrm{ml})$ and the highest in a Holstein-Friesian paternity cow $(142.4 \mathrm{mg} / \mathrm{ml})$.

The average dry matter content of the first-milked colostrum of HolsteinFriesian and Jersey paternity genotypes was 24.74\% (Csapó et al., 1982b, 1982c), which was 2-3\% lower than the result published by Sztarodubcev et al. (1974). Considering the average of the two genotypes, the total protein content of the first-milked colostrum was $14.94 \%$, whey protein content was $10.07 \%$, casein content was $4.87 \%$, and non-protein nitrogen $(\mathrm{NPN} \times 6.38$, calculated protein content) content was $0.43 \%$. According to our investigations (Csapó, 1995), the average total protein content of the two genotypes was 1.0$1.5 \%$ lower than in the results of Sztarodubcev et al. (1974), was more by the same amount than in the results of Grieb (1968), and 1.5-2.5\% higher than Voigtländer \& Glässer (1974) determined for German black-spotted. The whey protein content of the first milk colostrum was $10.02-10.12 \%$, while the average of the first three samplings was around $7.6 \%$. This last value, well approaching the $8.26 \%$ value, was measured by Kvapilik et al. (1975) and the one approaching the $8.35 \%$ value was measured by Grieb (1968) for colostrum sampled after five and a half hours after calving.

Many investigations were published about the dry matter content and protein fractions of colostrum (Grieb, 1968; Sztarodubcev et al., 1974; Voigtländer \& Glässer, 1974; Kvapiliket al., 1975). In examining the changes of the composition of the colostrum after calving as a function of time, it was concluded that significant changes in the dry matter, total protein, and whey protein content took place in the 24-hour period after calving, after which there was only a slight change in the composition of colostrum and transitional milk.

According to our investigations (Csapó et al., 1991a), the dry matter content of the colostrum was the lowest in the Jersey cow (19.4\%) and the highest in a Holstein-Friesian cow (31.2\%). The total protein content of the colostrum was the lowest in a Jersey cow $(10.23 \%)$ and the highest in a Holstein-Friesian cow $(21.7 \%)$. The whey protein content was the lowest in a Jersey cow $(7.32 \%)$ and the highest in a Holstein-Friesian cow (13.21\%). The lowest $(2.91 \%)$ and the highest $(7.12 \%)$ casein content were measured in two Holstein-Friesian cows. 
The NPN content was the lowest in a Jersey cow (0.29\%) and the highest $(0.53 \%)$ in a Holstein-Friesian cow.

We did not find literature data on the colostrum composition of the cows after twin-and triplet-calving.

\section{Materials and methods}

\subsection{The examined breeds, feeding and keeping conditions, sampling of colostrum and milk}

The genotype of the triplet-calving cows from Hajdúnánás was sired by Holstein-Friesian bulls $(62.5 \%$ Holstein-Friesian $+25 \%$ Jersey $+12.5 \%$ Hungarian red-spotted). The population of single-calving, twin-calving, and tripletcalving cows alike was under summer-feeding conditions, based chiefly on grass. Of the three cows calving triplet-calves, two were in the second and one in the third lactation.

Of the 17 twin-calving control cows, eight were in the $2^{\text {nd }}$ lactation and nine in the $3^{\text {rd }}$ lactation. Of the 17 single-calving cows, there were 10 in the second and seven in the third lactation. From each of the cattle stables of the Bos-Frucht Agricultural Cooperative, Kazsok and Gödöllö Experimental Farm Ltd., Kartal, we obtained the first colostrum of one triplet-calving HolsteinFriesian cow. Both cows started their $2^{\text {nd }}$ lactation and were mainly fed in a corn-based silage feeding system.

During the previous experiments, when the colostrum composition of the single- and twin-calving cows were compared, we sampled the colostrum, transient milk, and milk immediately after calving (within half an hour) and repeated it in the $12^{\text {th }}$ and $24^{\text {th }}$ hours as well as on the $2^{\text {nd }}, 3^{\text {rd }}$, and $5^{\text {th }}$ days after calving. However, as results showed that there are significant differences only in the first-milked colostrum between single- and twin-calving cows, when examining the influence of the number of offspring on colostrum composition, we focused only on the first-milked colostrum. In all cases, milk sampling took place from the mixed milk of the totally-milked udder. After homogenization, samples were stored in a deep freezer at $-25^{\circ} \mathrm{C}$.

\subsection{Analytical methods}

The frozen colostrum and milk samples were warmed up in $38-40{ }^{\circ} \mathrm{C}$ water, homogenized, and then dry matter content was determined by drying the sample to constant weight according to the Hungarian Standard MSZ-6830-6. 
The protein content and protein fractions of the samples were determined using Kjel-Foss 16200 nitrogen analyser. During the determination of the protein fractions, the whole milk $(\mathrm{N} \% \times 6.38=$ total protein $)$ was defatted by a T30-type laboratory centrifuge at 8,000 rev/minute for 10 minutes, and then the $\mathrm{pH}$ of the skim milk was set to $\mathrm{pH}=4.55$ with the help of an Op-264-type $\mathrm{pH}$ meter. The precipitated casein was removed by centrifugation at 8,000 $\mathrm{rev} /$ minute for 10 minutes from the whey $(\mathrm{N} \% \times 6.36=$ whey protein $)$. The whey protein was removed from the whey by $12 \%$ trichloroacetic acid precipitation, and the nitrogen content of the permeate was determined (non-protein nitrogen, NPN). By subtracting the NPN from the whole milk nitrogen, the milk true protein nitrogen was received, through the subtraction of the NPN from the whey nitrogen the true whey nitrogen was received, and through the subtraction of the whey nitrogen from the total nitrogen the casein nitrogen was received. The protein content of the different fractions was received after multiplying the nitrogen content of the fraction by 6.38 (conversion factor). Between 1980 and 2000, the nitrogen content of the milk samples and the different fractions were determined by Kjel-Foss 16200-type fast nitrogen analyser, while after $2000 \mathrm{Kjel-Tec} \mathrm{nitrogen} \mathrm{analyser} \mathrm{was} \mathrm{used} \mathrm{for} \mathrm{the} \mathrm{samples} \mathrm{of}$ the first three triplet-calving cows at the Chemical Institute of Kaposvár University, Faculty of Animal Science, and the nitrogen content of milk samples from the last two cows was determined at the Food Chemistry Department of Sapientia Hungarian University of Transylvania, Department of Food Science.

The IgG content of the colostrum was determined by the single radial immunodiffusion method described by Mancini et al. (1965). The anti-cattle IgG rabbit serum and the cattle IgG standard were obtained from the Human Vaccine and Research Institute (Budapest, Gödöllö, Hungary).

\subsection{Statistical analysis of the results}

The mean value and standard deviation of the results were calculated, and the mean values were compared with the help of Student t-test.

\section{Results and conclusions}

The dry matter content, protein content, and protein fractions of the firstmilked colostrum of the triplet-calving cows are shown in Table 1 and the concentration of the IgG in Table 2. In Table 3, the dry matter content and protein fractions and in Table 4 the $\operatorname{IgG}$ concentration of the first-milked colostrum of single-, twin-, and triplet-calving cows are compared. 
From the data of the first and second tables, it can be concluded that in the case of triplet-calving the concentrations of the dry matter, protein fractions, and immunoglobulin-G in first-milked colostrum are higher than the data published earlier in the literature. On the other hand, they are very similar to the data of twin-calving cows published by us earlier. There are very few data on the composition of first-milked colostrum in the literature because the sampling was not taken immediately after calving, for which reason the calves sometimes sucked before sampling, and the sucking stimulus caused attenuation in the colostrum. We can compare the $31.80 \%$ dry matter content value only to our earlier investigations or to the dry matter content of the first milk colostrum of twin-calving cows, which was $29.58 \%$. The $18 \%$ value for total protein content is also extremely high because total protein content in the literature is in most cases between 13 and 15\%, and this finding is valid for true protein $(17.26 \%$ ), whey protein $(13.79 \%)$, and true whey protein $(13.24 \%)$ as well. However, this is not surprising because the protein fractions listed here are all part of the total protein; accordingly, the substantially higher concentration found there is reflected in the protein fractions.

Table 1: Dry matter content, protein content, and protein fractions of the first colostrum of triplet-calving cows

\begin{tabular}{|c|c|c|c|c|c|c|}
\hline $\begin{array}{c}\text { Components } \\
\mathrm{g} / 100 \mathrm{~g}\end{array}$ & $\begin{array}{c}1 . \\
\operatorname{cow}^{1}\end{array}$ & $\begin{array}{c}2 . \\
\operatorname{cow}^{1}\end{array}$ & $\begin{array}{c}3 . \\
\operatorname{cow}^{1}\end{array}$ & $\begin{array}{c}4 . \\
\operatorname{cow}^{2}\end{array}$ & $\begin{array}{c}5 . \\
\text { cow }^{3}\end{array}$ & $\begin{array}{c}\text { Average } \\
\pm \mathrm{SD}\end{array}$ \\
\hline Dry matter & 31.43 & 30.89 & 31.12 & 32.61 & 32.93 & $31.80 \pm 0.92$ \\
\hline Total protein & 17.84 & 18.11 & 17.92 & 18.01 & 18.13 & $18.00 \pm 0.12$ \\
\hline True protein & 17.37 & 17.60 & 17.37 & 16.45 & 17.51 & $17.26 \pm 0.46$ \\
\hline Whey protein & 13.19 & 13.42 & 14.11 & 13.98 & 14.23 & $13.79 \pm 0.46$ \\
\hline True whey protein & 12.72 & 12.91 & 13.56 & 13.42 & 13.61 & $13.24 \pm 0.40$ \\
\hline Casein & 4.65 & 4.69 & 3.81 & 4.03 & 3.90 & $4.22 \pm 0.42$ \\
\hline $\mathrm{NPN} \times 6.38$ & 0.47 & 0.51 & 0.55 & 0.56 & 0.62 & $0.54 \pm 0.06$ \\
\hline
\end{tabular}

${ }^{1}$ Hajdúnánás State Farm

${ }^{2}$ Bos-Frucht Agricultural Cooperative, Kazsok

${ }^{3}$ Gödöllő Experimental Farm Ltd., Kartal

The $136.42 \mathrm{mg} / \mathrm{ml}$ for IgG is also one of the outstanding data in the literature. Only Senft et al. (1976) published in the literature a higher concentration than this one for IgG $(144 \mathrm{mg} / \mathrm{ml})$, which can be explained perhaps by the special keeping and feeding conditions, special environment, which made the animals produce such a high concentration of $\operatorname{IgG}$ in the colostrum. As for other researchers, they reported $100-120 \mathrm{mg} / \mathrm{ml}$ of IgG content of the colostrum at best and 50-70 at worst. 
Table 2: Immunoglobulin-G content of the first-milked colostrum of tripletcalving cows

\begin{tabular}{lcccccc}
\hline $\begin{array}{c}\text { Components } \\
\mathbf{m g} / \mathbf{c m}^{\mathbf{3}}\end{array}$ & $\begin{array}{c}\mathbf{1 .} \\
\mathbf{c o w}^{\mathbf{1}}\end{array}$ & $\begin{array}{c}\mathbf{2 .} \\
\mathbf{c o w}^{\mathbf{1}}\end{array}$ & $\begin{array}{c}\mathbf{3 .} \\
\mathbf{c o w}^{\mathbf{1}}\end{array}$ & $\begin{array}{c}\mathbf{4 .} \\
\mathbf{c o w}^{\mathbf{2}}\end{array}$ & $\begin{array}{c}\mathbf{5 .} \\
\mathbf{c o w}^{\mathbf{3}}\end{array}$ & $\begin{array}{c}\text { Average } \\
\pm \mathbf{S D}\end{array}$ \\
\hline $\mathrm{IgG}$ & 132.8 & 133.1 & 139.7 & 135.3 & 141.2 & $136.42 \pm 3.84$ \\
\hline${ }^{1}$ Hajdúnánás State Farm \\
${ }^{2}$ Bos-Frucht Agricultural Cooperative, Kazsok \\
${ }^{3}$ Gödöllö Experimental Farm Ltd., Kartal
\end{tabular}

Table 3: Dry matter and protein content as well as protein fractions of firstmilked colostrum from single-, twin-, and triplet-calving cows

\begin{tabular}{lccc}
\hline $\begin{array}{c}\text { Component } \\
\mathbf{g} / \mathbf{1 0 0 g}\end{array}$ & $\begin{array}{c}\text { Single-calving } \\
(\mathbf{n}=\mathbf{1 7})\end{array}$ & $\begin{array}{c}\text { Twin-calving } \\
(\mathbf{n}=\mathbf{1 7})\end{array}$ & $\begin{array}{c}\text { Triplet-calving } \\
(\mathbf{n}=\mathbf{5})\end{array}$ \\
\hline Dry matter & $24.73 \pm 2.31$ & $29.58 \pm 1.93$ & $31.80 \pm 0.92$ \\
Total protein & $14.71 \pm 1.62$ & $17.32 \pm 1.39$ & $18.00 \pm 0.12$ \\
True protein & $14.19 \pm 1.44$ & $16.89 \pm 1.40$ & $17.26 \pm 0.46$ \\
Whey protein & $10.22 \pm 1.43$ & $12.99 \pm 1.32$ & $13.79 \pm 0.46$ \\
True whey protein & $9.71 \pm 1.28$ & $12.56 \pm 1.34$ & $13.24 \pm 0.40$ \\
Casein & $4.50 \pm 0.91$ & $4.33 \pm 0.69$ & $4.22 \pm 0.42$ \\
NPN $\times 6.38$ & $0.52 \pm 0.094$ & $0.43 \pm 0.137$ & $0.54 \pm 0.06$ \\
\hline
\end{tabular}

Table 4: Immunoglobulin-G content of the first-milked colostrum of single-, twin-, and triplet-calving cows

\begin{tabular}{lccc}
\hline $\begin{array}{c}\text { Component } \\
\mathbf{m g} / \mathbf{c m}^{3}\end{array}$ & $\begin{array}{c}\text { Single-calving } \\
(\mathbf{n}=\mathbf{1 7})\end{array}$ & $\begin{array}{c}\text { Twin-calving } \\
(\mathbf{n}=\mathbf{1 7})\end{array}$ & $\begin{array}{c}\text { Triplet-calving } \\
(\mathbf{n}=\mathbf{5})\end{array}$ \\
\hline $\mathrm{IgG}$ & $104.51 \pm 14.5$ & $128.15 \pm 18.81$ & $136.42 \pm 3.84$ \\
\hline
\end{tabular}

The purpose of this study was not to compare our results to those published in the literature but to compare the composition of the first-milked colostrum of twin-calving and triplet-calving cows living in the same keeping and feeding conditions, in the same environment and to focus on how to influence the composition of the first-milked colostrum in twin- and triplet-calving cows. The results of these investigations are shown in tables 3 and 4 . Earlier we discovered (Csapó et al., 1991a; Csapó, 1995) that the sex of the offspring at twin-calving had no influence on the composition of the first milk colostrum; for some reason, this aspect - among others, due to the low number of tripletcalving cows - was not investigated. 
It has also turned out from our previous investigations that the first colostrum of the twin-calving animals has significantly more dry matter, total protein, true protein, whey protein, true whey protein, and IgG content than that of single-calving animals. In addition, we found no significant differences in the casein and NPN content of the two groups. We assumed that these differences also existed between single- and triplet-calving animals, wherefore we wished to examine in particular that triplet-calving can lead to further increase in the concentration of the dry matter content, protein fractions, and especially $\operatorname{IgG}$ content of first-milked colostrum.

From the results of the statistical analysis, it can be seen that the first colostrum of the triplet-calving animals has significantly $(\mathrm{P}<0.001)$ more dry matter, total protein, true protein, whey protein, and true whey protein content than that of single-calving cows. In the case of casein and NPN content, there were no significant differences between the three groups. It was not found any significant differences between the twin-calving cows and triplet-calving cows. The first-milked colostrum of the triplet-calving cows had $2.22 \%$ more dry matter, $0.68 \%$ more total protein, $0.37 \%$ more true protein, $0.80 \%$ more whey protein, $0.68 \%$ more true whey protein, $0.11 \%$ less casein, and $0.11 \%$ more NPN $\times 6.38$ than that of twin-calving animals.

The IgG content of the first-milked colostrum was measured at singlecalving: 104.51, twin-calving: 128.15, and triplet-calving: $136.42 \mathrm{mg} / \mathrm{ml}$, which reveal significant differences between the single- and triplet-calving animals. Although the first-milked colostrum of triplet-calving animals had 8.27 $\mathrm{mg} / \mathrm{ml}$ more IgG, the difference was not significant between the two groups.

Based on the foregoing, the first-milked colostrum of the triplet-calving animals has more protein, and in it more whey protein, than approximately the same amount of casein as the single- and twin-calving animals, as proved to be the case, but significant differences between the twin- and triplet-calving animals could not be detected.

Finally, there is a single question to be answered: what causes the difference in the composition of the first-milked colostrum of single-, twin-, and tripletcalving animals? There is a clear response to it: $\operatorname{IgG}$ is part of the whey protein, the whey protein is part of total protein, and the received differences are primarily due to IgG or whey protein surplus. But what cause the differences between the groups during pregnancy?

Of the hormones that control the function of the mammary gland, there is only one whose concentration is influenced by twin pregnancy - that is the placental lactogen $(\mathrm{PL})$, which is produced by the placenta and which enhances cell protein synthesis and cell division in the body. Besides the oestrogens, 
it is crucial to mammogenesis. As in humans there is a close correlation between the size of the placenta and the production of PL, our premise is that two and three placentas will produce more placental lactogen than only one, which leads to increased protein production and increased concentration of immunoglobulin-G and of different protein fractions in the first-milked colostrum.

\section{Acknowledgement}

Our study was supported by the EFOP-3.6.3-VEKOP-16-2017-00008 project. The project is co-financed by the European Union and the European Social Fund. We wish to express our gratitude for the support offered by Sapientia Hungarian University of Transylvania (Cluj-Napoca), Faculty of Economics, Socio-Human Sciences and Engineering, Department of Food Science (Miercurea Ciuc).

\section{References}

[1] J. E. Butler, Bovine immunoglobulins: A review. Journal of Dairy Science, 52. 12. (1969) 1895-1909.

[2] J. Csapó, Zs. Csapó, B. Makay, A kolosztrum és az átmeneti tej makroés mikroelem-tartalmának vizsgálata eltérő genotípusú teheneken [Examination of the micro- and macroelement content of the colostrum at different genotypes of cattle]. Szaktanácsok, 3-4. (1982a) 5-12.

[3] J. Csapó, A. M. Horváthné, B. Makay, Holstein-fríz, magyar tarka és magyar tarka $\times$ Holstein-fríz $\left(F_{1}\right)$ tehenek föcsteje és átmeneti teje szárazanyag-, nyersfehérje-, savófehérje-, kazein- és nem-fehérje nitrogen tartalmának összehasonlítása [Comparison of the dry matter-, crude protein-, whey protein-, casein- and non-proteinic nitrogen content of colostrum and transition milk of Holstein-Friesian and Hungarian red spotted $\times$ Holstein-Friesian $\mathrm{F}_{1}$ cows]. Magyar Állatorvosok Lapja, 6. (1982b) 411-414.

[4] J. Csapó, B. É. Terlakyné, Zs. Csapó, B. Makay, Holstein-fríz, magyar tarka és magyar tarka $\times$ Holstein-fríz $\left(\mathrm{F}_{1}\right)$ tehenek föcstejének, átmeneti tejének és tejfehérjéjének aminosav összetétele, valamint aminosav összetételének vizsgálata az ellés után [Amino acid composition as 
well as examination of the amino acid composition after calving of the colostrum-, transition milk- and milk protein of Holstein-Friezian and Hungarian red spotted $\times$ Holstein-Friesian $\left(\mathrm{F}_{1}\right)$ cows]. Magyar Állatorvosok Lapja, 6. (1982c) 415-419.

[5] J. Csapó, Zs. Csapó, A hungaro-fríz alapon végzett Jersey és Holsteinfríz criss-cross keresztezés hatása a kolosztrum és a tej összetételére [Influence of the Holstein-Friesian and Jersey criss-cross breeding programme on the basis of Hungaro-Friesian for the colostrum and milk composition]. Szaktanácsok, 1. (1984) 32-37.

[6] J. Csapó, Gy. Wolf, Zs. Csapó-Kiss, J. Szentpéteri, J. Kis, Ikreket ellett szarvasmarhák kolosztrumának összetétele [Colostrum composition of the cows producing twins]. Állattenyésztés és Takarmányozás, 40. 3. (1991a) 231-238.

[7] J. Csapó, Gy. Wolf, Zs. Csapó-Kiss, J. Szentpéteri, J. Kiss, Composition of colostrum from twinning cattle. Acta Agronomica Hungarica, 40. (1991b) 152-157.

[8] J. Csapó, Kérődző háziállataink kolosztrum és tejösszetétele és néhány összetevő analitikája [Colostrum and milk composition of ruminant domestic animals and the analytics of some compounds]. Akadémiai doktori értekezés, Kaposvár. (1995) 171.

[9] J. Csapó, Estimation of immunoglobulin-G content of colostrum and milk from whey protein content of ruminant animals. Acta Universitatis Sapientiae, Alimentaria, 6. (2013) 15-22.

[10] P. Ehrlich, Über Immunität durch Vererbung und Zeugung. Zeitschrift für Hygiene und Infektionskrank, 12. (1892) 183.

[11] G. Grieb, Untersuchungenüber die Kolostrumperiode des Kalbesüber den Eiweiss- und Vitamin-A-Gehalt der Kolostralmilchsowie der Milch in den ersten 30 Laktationstagen. 1. Mitteilung: Der Eiweissgehalt der Kolostralmilch und Milch. Archive für Tierzucht, 11. (1968) 151-163.

[12] J. Kvapilik, B. Suchánek, J. Brauner, Premenamlezivanamlékozralé se zamerenimnajehochemické a technologickévlastnosti. Zivocisna Vyroba, 20. (1975) 169-182. 
[13] E. F. Logan, D. J. Meneely, A. Lindsay, Colostrum and serum immunglobulin levels in jersey cattle. British Veterinary Journal, 137. (1981) 279-282.

[14] S. Losonczy, Gy. Pethes, V. L. Frenyó, T. Antal, I. Szabó, Gyors élettani módszer a borjak optimális kolosztrumitatásának nagyüzemi körülmények közötti ellenőrzésére. I. A borjak pre- és posztkolosztrális szérum IgG koncentrációjának alakulása [Fast physiological method for monitoring the colostrum consumption of calves under state farm circumstances: I. Changes in the pre- and postcolostral serum IgG concentration]. Magyar Állatorvosok Lapja, 34. (1979) 371-375.

[15] G. Mancini, A. O. Carbonara, J. F. Heremans, Immunochemical quantitation of antigens by single radial immunodifusion. Immunochemistry, 2. (1965) 3. 235-254.

[16] T. C. McGuire, N. E. Pfeiffer, J. M. Weikel, C. R. Bartosch, Failure of colostral immunoglobulin transfer in calves dying from infectious disease. Journal of American Veterinary Medical Association, 169. (1976) 713-718.

[17] H. Mielke, Theoretische und praktische Aspekte der Ausbildung und Bewertung der kolostralen Immunität sowie Möglichkeiten einergezielten Immunprophylaxe beim Kalb. Immunologie, 34. (1979a) 223-229.

[18] H. Mielke, Geschichtliches und Grundlagen der immunbiologischen Beziehungenzwischen Muttertier und Fruchtbeim Rind. Immunologie, 34. (1979b) 217-223.

[19] B. Senft, F. Klobasa, R. Meyer, U. E. Pfleiderer, Untersuchungenüber Lactoferrin und IgG in der Kuhmilch. 1. Variabilität in der Konzentrationwährend der Laktation. Züchtungskunde, 48. (1976) 278-288.

[20] M. Sztarodubcev, A. A. Logacseva, T. P. Konjajeva, Szosztav i biologicseszkije szvojsztva moloziva korov pjáti porod. Veszt. Szel'szkohozj. Nauki, 12. (1974) 40-46.

[21] K. H. Voigtländer, H. L. Glässer, Die Veränderungen der Zusammensetzung von Kolostralmilch und transitorischer Milch. Archive für Tierzucht, 17. (1974) 107-118. 